\title{
UNIQUe LEgal CONSIDERATIONS IN REALITY TELEVISION
}

\author{
By Katie Hopkins* \\ Volume XIII - Fall 2012
}

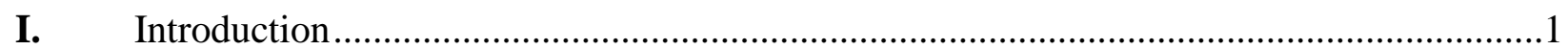

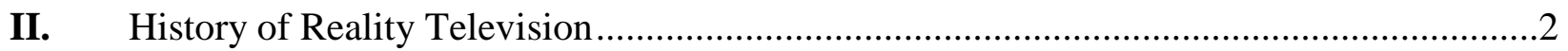

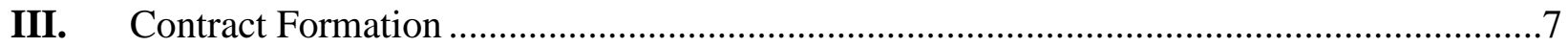

IV. Abuse of the Bargaining Process - Unconscionability ……….......................................

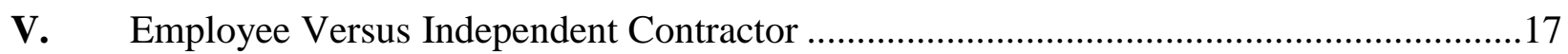

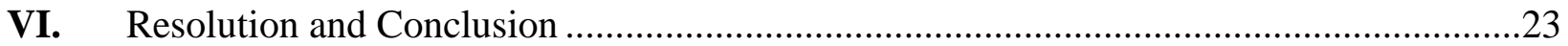

\footnotetext{
* Katie Hopkins is a JD/MBA Candidate 2014, University of Pittsburgh School of Law and Tepper School of Business at Carnegie Mellon University; BBA 2008, University of Notre Dame.
} 


\section{INTRODUCTION}

Jill Mouser was hoisted into a "harness of pain" for a period of forty minutes, leaving her screaming in excruciating misery, all for a reality television program, Culture Shock, that never aired. ${ }^{1}$ Following this stunt, Mouser was injected with morphine and taken off to the hospital. ${ }^{2}$ Mouser filed suit against CBS for injuries resulting from filming the show. ${ }^{3}$ Mouser had signed two different waivers of her rights before partaking in the aforementioned stunt. ${ }^{4}$

Reality television has become progressively outrageous. ${ }^{5}$ Producers thus attempt to enter into contractual relationships with reality show stars or contestants, whereby producers can avoid liability to both the "actors" and any third parties. Producers place the actors in situations where harm is imminent to either the actors themselves or the third parties. Yet, producers shield themselves from liability despite their encouragement of dangerous behavior.

This article will take a critical look at the methods used by producers and networks to avoid legal liability in the reality television industry. Section II of this article sets forth a brief history of reality television. Section III describes the typical process of contract formation and its application within the reality television industry. Section IV lays out the test for determining unconscionability of a contract and examines reality television contract provisions and contract formation under this lens. Section V analyzes the relationship between reality television producers and actors, and suggests that the relationship fits more closely with that of an employer-employee relationship as opposed to an independent contractor relationship. Lastly,

\footnotetext{
${ }^{1}$ Lawsuit: CBS Used "Harness of Pain", THE SMOKING Gun (Dec. 1, 2002), http://www.thesmokinggun.com/documents/crime/lawsuit-cbs-used-harness-pain.

${ }^{2}$ Id.

${ }^{3} I d$.

${ }^{4}$ Adam Liptak, Growing Rowdier, TV Reality Shows Are Attracting Suits, N.Y. TIMES, Jan. 7, 2003, http://www.nytimes.com/2003/01/07/us/growing-rowdier-tv-reality-shows-are-attractingsuits.html?pagewanted=all\&src=pm.

${ }^{5}$ Chris Serres, Reality TV Gives Insurers the Jitters, STARTRIBBUNE.COM, http://www.lmcsofttest.com/MSNBC\%20-\%20Reality\%20TV\%20gives\%20insurers\%20the\%20jitters.htm (last visited Nov. 11, 2012).
} 
part VI concludes by arguing that the unique nature of reality television calls for a greater imposition of responsibility on the programs' producers and the attempts to avoid liability for actions encouraged by these producers should be monitored with a critical eye.

\section{HiSTORY OF REALITY TELEVISION}

"Reality television is located in border territories, between information and entertainment, documentary and drama." ${ }^{\prime 6}$ Reality television is a form of non-fiction television programming that encompasses a broad spectrum of different programs. ${ }^{7}$ Makeover programs, talent contests, dating shows, court programs, and reality-based sitcoms constitute a handful of the varying programs often classified under this catch-all category known as reality television. ${ }^{8}$ Common features in reality television include the use of ordinary people (non-actors), unscripted dialogue (or minimal writing), surveillance footage, and hand-held cameras. ${ }^{9}$

The roots of reality television can be traced back to over 60 years ago in programs such as Queen for a Day, Bride and Groom, and Candid Camera. ${ }^{10}$ Queen for a Day, on which contestants told sob stories in hopes of being selected as the "queen for a day" and given a prize, began as a radio program, was shown on Los Angeles local television beginning in 1948, and was later picked up by NBC and subsequently, by ABC. ${ }^{11}$ Bride and Groom featured on-air

\footnotetext{
${ }^{6}$ AnNetTe Hill, ReAlity TV: AUdiEnCES AND POPUlAR FACTUAL TELEVISION 2(Routledge, 2005).

${ }^{7}$ SU HOLMES \& DEBORAH JERMYN, Introduction to UNDERSTANDING REALITY TELEVISION 2 (Routledge, 2004).

${ }^{8}$ HORACE NEWCOMB, Encyclopedia of Television (Routledge, 2d ed. 2004), available at http://cw.routledge.com/ref/television/realitytv.html.

${ }^{9}$ HILL, supra note 6, at 41; Susan Murray \& Laurie Ouellette, Introduction, in REALITY TV: REMAKING TELEVISION Culture 3 (NYU Press, 2009).

${ }^{10}$ NewCOMB, supra note 8; Dave Rasdal, “Reality TV” Marriage Celebrates 60 Years, THE GAZETTE (Aug. 6, 2012), http://thegazette.com/2012/08/06/reality-tv-marriage-celebrates-60-years/.

${ }^{11}$ Queen for a Day (NBC television broadcast 1956), TV.COM, http://www.tv.com/shows/queen-for-a-day/ (last visited Nov. 2, 2012).
} 
weddings with prizes for the couple. ${ }^{12}$ Candid Camera used undercover cameras to catch unsuspecting people in embarrassing positions. ${ }^{13}$ In the 1950 s, game shows, such as What's My Line, became popular. ${ }^{14}$ In the 1970s and 1980s, programs (including An American Family, Real People, and That's Incredible) began to shoot people in their real-life settings rather than in studios. ${ }^{15}$ Although these programs resembled documentaries, they went beyond mere observation in order to portray a more artful story, which was created through careful editing. ${ }^{16}$ In the late 1980s, writer strikes caused networks to become more reliant on reality programs because writers were not needed to write scripts for such programs. ${ }^{17}$ The networks began to discover the economic benefits of reality television because not only did it provide them with an ability to avoid strikes, but also, these programs typically called for less-talented actors or ordinary people and the production costs tended to be much lower. ${ }^{18}$ Popular reality programs during this era included COPS, Unsolved Mysteries, America's Funniest Home Videos, and Rescue $911 .{ }^{19}$ Syndicated talk shows, such as Oprah, became popular at this time as well. ${ }^{20}$ This popularity can be attributed to the exposition of the personal struggles of ordinary people as well as the opportunity for audience participation, allowing viewers to experience a deeper connection with the shows. $^{21}$

\footnotetext{
${ }^{12}$ Bride and Groom, INTERNET MOVIE DATABASE, http://www.imdb.com/title/tt0050001/ (last visited Nov. 2, 2012) (describing the show Bride and Groom).

${ }^{13}$ NewCOMB, supra note 8; Candid Camera, INTERNET Movie DATABASE, http://www.imdb.com/title/tt0053489/ (last visited Nov. 2, 2012).

${ }^{14}$ Charles B. Slocum, The Real History of Reality TV, WGAW, http://www.wga.org/organizesub.aspx?id=1099 (last visited Nov. 2, 2012).

${ }^{15} I d$.

${ }^{16} I d$.

${ }^{17}$ NEWCOMB, supra note 8.

${ }^{18} \mathrm{Id}$.

${ }^{19} \mathrm{Id}$.

${ }^{20} \mathrm{Id}$.

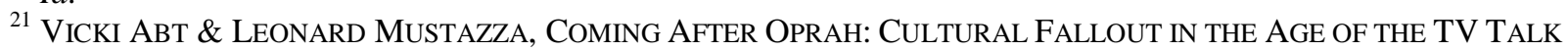
SHOw 2 (Bowling Green State University Popular Press, 1997).
} 
In 1992, MTV aired its premiere of reality television program, The Real World. ${ }^{22}$ Many believe The Real World is responsible for starting a new wave of reality programming. ${ }^{23}$ The plot of The Real World is demonstrated by the opening credits which state, "This is the true story of seven strangers picked to live in a house and have their lives taped. Find out what happens when people stop being polite and start getting real. The Real World..."24 The Real World has been a major success for MTV. ${ }^{25}$ In fact, the $27^{\text {th }}$ season, Real World: St. Thomas, recently finished airing. ${ }^{26}$ Several features of The Real World have been embedded in the world of reality programs including: a staged environment in which "reality" can occur, confessional interviewing, and editing decisions of who and what to show. ${ }^{27}$

The real explosion in reality television is often attributed to Survivor and Big Brother, both of which first aired in $2000 .^{28}$ Survivor features ordinary people as contestants, who are isolated in the wilderness and participate in different competitions with each other, both in teams and individually. ${ }^{29}$ Contestants on Survivor vote off other contestants until the lone winner remains. ${ }^{30}$ On Big Brother, contestants live in an isolated house together, competing to survive evictions in hopes of winning half a million dollars. ${ }^{31}$

Since 2000, reality television programs have launched at a record pace. ${ }^{32}$ Reality programs span almost any area you can imagine. Reality TV World provides a list of over 1,000

\footnotetext{
${ }^{22}$ The Real World, TV.COM, http://www.tv.com/shows/the-real-world/ (last visited Nov. 2, 2012).

${ }^{23}$ NEWCOMB, supra note 8.

${ }^{24}$ The Real World, supra note 22.

${ }^{25}$ Stephanie Goldberg, 'The Real World' Turns 20, CNN (May 23, 2012), http://www.cnn.com/2012/05/23/showbiz/tv/real-world-mtv-20-years/index.html.

${ }^{26}$ See id. See also Real World: St. Thomas, MTV.COM, http://www.mtv.com/shows/real_world/st_thomas/series.jhtml (last visited Nov. 2, 2012).

${ }^{27}$ Slocum, supra note 14.

${ }^{28}$ See id. See also NEWCOMB, supra note 8.

${ }^{29}$ Survivor, TV.COM, http://www.tv.com/shows/survivor/ (last visited Nov. 2, 2012).

${ }^{30} \mathrm{Id}$.

${ }^{31}$ Big Brother, TV.COM, http://www.tv.com/shows/big-brother/ (last visited Nov. 2, 2012).

${ }^{32}$ See NEWCOMB, supra note 8.
} 
different reality television programs. ${ }^{33}$ Examples of more obscure reality programs include Ghost Hunters, a paranormal reality program in which two men track down the presence of paranormals in haunted places, and Duck Dynasty, a reality show based on a family who owns a company that makes duck calls. ${ }^{34}$ Popular reality television programs as of late include the likes of The Bachelor, American Idol, The Voice, X Factor, America's Got Talent, Dancing with the Stars, Hell's Kitchen, The Biggest Loser, among many others. ${ }^{35}$ Reality show programs captured two of the top three spots on a list which ranked the most popular television shows of 2011$2012 .{ }^{36}$

Despite the proliferation and popularity of reality television programs, there are risks present in reality shows that are either absent or exist to a lower degree in more traditional television programming. Reality programs present high psychological risks to the cast. ${ }^{37}$ In a number of reality television programs, the cameras are essentially always rolling. Thus, because of the seemingly endless footage, show producers and editors have broad discretion in selecting what they want to air. In effect, many reality television stars end up feeling as if they are portrayed in a manner inconsistent with their actions. ${ }^{38}$ A number of contestants have experienced depression following their participation in reality television programs. ${ }^{39}$ Expedition

\footnotetext{
${ }^{33}$ All Shows Listed Alphabetically, REALITY TV WORLD, http://www.realitytvworld.com/realitytvworld/allshows.shtml (last visited Nov. 2, 2012).

${ }^{34}$ Ghost Hunters: About, SYFY, http://www.syfy.com/ghosthunters/about (last visited Nov. 2, 2012); Duck Dynasty: About the Show, A\&E, http://www.aetv.com/duck-dynasty/about/ (last visited Nov. 2, 2012).

${ }^{35}$ Andy Dehnart, 2011-2012's Reality Shows, Ranked by Ratings Popularity, REALITY BLURRED (May 25, 2012, 8:55 AM), http://www.realityblurred.com/realitytv/archives/industry_news/2012_May_25_ratings-2011-2012.

${ }^{36}$ Bill Gorman, Complete List of 2011-2012 Season TV Show Ratings: 'Sunday Night Football' Tops, Followed by 'American Idol,' 'The Voice' \& 'Modern Family', TV BY THE NuMBERS (May 24, 2012), http://tvbythenumbers.zap2it.com/2012/05/24/final-list-of-2011-12-season-tv-show-ratings-sunday-night-footballtops-followed-by-american-idol-the-voice-modern-family/135747/.

${ }^{37}$ Reality TV Under Fire, BBC News (Aug. 27, 2001, 13:16 PM), http://news.bbc.co.uk/2/hi/entertainment/1511775.stm.

${ }^{38} I d$.

${ }^{39}$ See Debra Smith, The 16th minute: Understanding the phenomenon of short-term fame among reality TV show contestants (2010) (thesis, California State University, Fullerton) (on file with ProQuest Dissertations \& Theses database).
} 
contestant, Sinisa Savija, committed suicide shortly after he was cut from the show. ${ }^{40}$ Savija's widow claimed that he became severely depressed after his participation in the show and he worried that the producers would edit the film, portraying him as a fool. ${ }^{41}$ Simon Foster also took his own life after his marriage collapsed following his appearance on reality television show, The Wife Swap. ${ }^{42}$ A friend of Simon's discussed the amount of strain that Simon felt from the show, noting that, "he was never really the same" after the show because his family's alternative lifestyle made him into a "laughingstock."43 Although neither of these suicides can be conclusively or wholly attributed to the reality television programs, the psychological effects of reality television are substantial dangers for contestants.

In addition to psychological risks, reality programs often put the cast members in physical danger. ${ }^{44}$ In fact, the producers appear to promote dangerous behavior to provide a more entertaining show. ${ }^{45}$ For instance, in a competition on Fear Factor, contestants retrieved cow tongues from animal lard and subsequently, exchanged the tongues by their mouths. ${ }^{46}$ Insurance company, St. Paul Travelers Companies Inc., declined to insure a show in which producers wanted to fake an airplane engine failure in order to force people to jump out of the plane with parachutes while taping the staged act on a hidden camera. ${ }^{47}$ Many reality shows

\footnotetext{
${ }^{40}$ Gloria Hillard, Survivor Questioning Candidates and the Game, CNN (Oct. 21, 1999), http://articles.cnn.com/1999-10-21/entertainment/9910_21_survivor_1_expedition-robinson-game-show-bosnianrefugee?_s=PM:SHOWBIZ.

${ }^{41} I d$.

${ }^{42}$ Simon Foster, Wife Swap (England), REALITY SHOW SuICIDES (Apr. 15, 2008), http://www.realityshowsuicides.com/simon-foster-wife-swap-england/.

${ }^{43}$ Frank Feldinger, TheWrap Investigates: 11 Players Have Committed Suicide, THE WRAP, http://www.thewrap.com/tv/article/thewrap-investigates-11-reality-show-players-have-committedsuicide_3409?page $=0,3$ (last visited Nov. 2, 2012).

${ }^{44}$ See Serres, supra note 5.

${ }^{45}$ See id.

${ }^{46} \mathrm{Id}$.

${ }^{47}$ Id.
} 
encourage drinking, often excessively. ${ }^{48}$ In fact, one contestant made a statement that she was, "drunk or close to it in 90 percent of her on-air scenes." ever wanted something to drink, it was made available... Whereas if you requested tampons you'd have to wait a couple days. $" 50$

As the amount of the reality shows has increased dramatically, producers are constantly thinking of new ideas, often more obscure and dangerous than the last. ${ }^{51}$ Viewers seem drawn to scandal and shocking situations. ${ }^{52}$ It comes as no surprise that the risks involved in reality shows would cause harms, resulting in lawsuits. Thus, producers use a number of methods in an attempt to avoid legal liability for misfortunes occurring in connection with reality programming. Namely, producers draft contracts with extensive waivers for contestants to sign, and characterize the relationship between the producer and the employee as one of an independent contractor as opposed to an employer-employee relationship.

\section{CONTRACT FORMATION}

In order to form a valid contract, there must be "a bargain in which there is a manifestation of mutual assent to the exchange and a consideration." ${ }^{, 53}$ Mutual assent is typically manifested through an offer and an acceptance. ${ }^{54}$ An offer communicates, by words or acts, what the offeror will give in return for a promise or performance of an act by the offeree. ${ }^{55}$ An

\footnotetext{
${ }^{48}$ Heather Fletcher, Drink Up. It's Not Like You Have Hard Lines to Learn, NY TIMES, Oct. 29, 2006, http://www.nytimes.com/2006/10/29/arts/television/29flet.html?pagewanted=all\&_r=1\&.

${ }^{49} I d$.

${ }^{50} \mathrm{Id}$.

${ }^{51}$ Serres, supra note 5.

${ }^{52}$ See id.

${ }^{53}$ RESTATEMENT (SECOND) OF CONTRACTS $§ 17$ (1981).

${ }^{54} \mathrm{Id}$. at $\S 18$.

55 See Starr Farm Beach Campowners Ass'n, Inc. v. Boylan, 811 A.2d 155, 158-59 (Vt. 2002); see also Mencher v. Weiss, 114 N.E.2d 177, 182 (N.Y. 1953).
} 
offer is made when it is received. ${ }^{56}$ An offer should cause an offeree to reasonably believe that an offer has been made and that he or she can accept the offer, thereby binding the offeror. ${ }^{57}$ Preliminary negotiations do not constitute an offer. ${ }^{58}$ Additionally, courts typically require the terms of an offer to be reasonably certain. ${ }^{59}$ Acceptance is a "manifestation of assent to the terms thereof made by the offeree in a manner invited or required by the offer." ${ }^{\text {"6 }}$ An offer can invite acceptance by words, by performing an act, by refraining to perform a certain act, or by allowing the offeree to select how to accept. ${ }^{61}$ If the offer does not indicate a method of acceptance, acceptance can be, "in any manner and by any medium reasonable in the circumstances." ${ }^{62}$ Consideration is a bargained-for-exchange, meaning that something of value is given in exchange for a performance or a promise to perform. ${ }^{63}$

The contract formation process for reality television is, on its face, not substantially dissimilar to other contracts in the entertainment industry. The offer typically comes in the form of a written contract from the producer or network. ${ }^{64}$ Acceptance is typically required to be in the form of writing, i.e., a signature on the written contract, promising performance. ${ }^{65}$ In terms of consideration, reality show contestants often receive compensation or compensation-in-kind (i.e., housing, food, etc.) as well as an opportunity to be in the spotlight in exchange for their performance as contestants or stars on the show. ${ }^{66}$

\footnotetext{
${ }^{56}$ See Caldwell v. Cline, 156 S.E. 55, 56 (W. Va. 1930).

${ }^{57}$ See Nordyne, Inc. v. Int'l Controls \& Measurements Corp., 262 F.3d 843, 846 (8th Cir. 2001); Architectural Metal Systems, Inc. v. Consolidated Systems, Inc., 58 F.3d 1227, 1229 (7th Cir. 1995); Donovan v. RRL Corp., 27 P.3d 702, 709 (Cal. 2001); Heartland Express, Inc. v. Terry, 631 N.W.2d 260, 268 (Iowa 2001).

${ }^{58}$ Neff v. World Pub. Co., 349 F.2d 235, 248 (8th Cir. 1965).

${ }^{59}$ See e.g., Dyno Const. Co. v. McWane, Inc., 198 F.3d 567 (6th Cir. 1999).

${ }^{60}$ RESTATEMENT (SECOND) OF CONTRACTS § 50 (1981).

${ }^{61} I d$. at $\S 30$.

${ }^{62} I d$.

${ }^{63}$ See Deli v. Hasselmo, 542 N.W.2d 649, 656 (Minn. Ct. App. 1996); Campi v. Seven Haven Realty Co., 682 A.2d 281 (N.J. Super. Ct. Law Div. 1996).

${ }^{64}$ See SAm Brenton \& Reuben Cohen, Shooting People: Adventures in Reality TV (Verso, 2003).

${ }^{65}$ See Lawsuit: CBS Used "Harness of Pain", supra note 1.

${ }^{66}$ See BRENTON \& COHEN, supra note 64, at 125.
} 
Although this contract formation process seems to mimic the process of other television shows or film contracts, the difference lies in the bargaining process. ${ }^{67}$ In the film industry and in more traditional television programming, the talent is represented by experienced agents. ${ }^{68}$ Agents often enter into a non-binding preliminary agreement (known as "memorandum of understanding" or "letter of intent") prior to the formal contract, describing the terms of the contract. ${ }^{69}$ In fact, it is common for film studios to never formalize the deal, especially when dealing with higher-value talent. ${ }^{70}$ In contrast, reality show contestants typically do not have agents and are not experienced in the bargaining process. ${ }^{71}$ Furthermore, it is unlikely that the contestants could command producers to enter into less formal agreements or provide more favorable terms to the contestants because, for the most part, the contestants are highly dispensable. $^{72}$ They are typically just ordinary people. ${ }^{73}$ Thus, the resulting contracts in reality television contain terms that are substantially favorable to the drafting party.

\section{Abuse of the Bargaining Process - Unconscionability}

If a contract is found to be unconscionable, courts are permitted to refuse to enforce the contract in whole or in part. ${ }^{74}$ The UCC version of this common law defense to enforcing a contract, provides, "If the court as a matter of law finds the contract or any clause of the contract to have been unconscionable at the time it was made the court may refuse to enforce the contract, or it may enforce the remainder of the contract without the unconscionable clause, or it may so

\footnotetext{
${ }^{67}$ See Jonathan Barnett, Hollywood Deals: Soft Contracts for Hard Markets, CENTER IN LAW, ECON., \& ORG. Research PAPERS Series No. C12-9, Legal Studies Research PAPER SERIES No. 12-15 (July 27, 2012), available at http://lawweb.usc.edu/centers/cleo/working-papers/cleo/documents/C12_9_paper.pdf.

${ }^{68} I d$.

${ }^{69}$ Id. at 8 .

${ }^{70}$ Id. at $10-11$.

${ }^{71}$ See Barnett, supra note 67.

${ }_{73}^{72}$ See HILL, supra note 6.

${ }^{73} \mathrm{Id}$.

${ }^{74}$ Armendariz v. Found. Health Psychcare Servs., Inc., 6 P.3d 669, 696 (Cal. 2000).
} 
limit the application of any unconscionable clause as to avoid any unconscionable result."75

Although the UCC does not apply to contracts for services, the courts' analysis for unconscionability of service contracts is essentially the same. ${ }^{76}$ In order to determine unconscionability, courts must find, "an absence of meaningful choice on the part of one of the parties together with contract terms which are unreasonably favorable to the other party."77

In determining whether there is an absence of meaningful choice (procedural element of unconscionability), courts often look to whether there is unequal bargaining power. ${ }^{78}$ Some of the circumstances that the courts have considered in determining whether there is unequal bargaining power include age, education, intelligence, business acumen and experience. ${ }^{79}$ In Williams v. Walker-Thomas Furniture Co., the clients were of low income and found to have a gross inequality in bargaining power, thus lacking meaningful choice. ${ }^{80}$ Yet, in Denlinger, Inc. v. Dendler, Dendler was not found to be lacking meaningful choice because he was an experienced businessman, rather than a general consumer. ${ }^{81}$ Courts will also consider a party’s relative bargaining power, including which party drafted the contract, whether the terms were explained to the weaker party, and whether changes in the contract were possible. ${ }^{82}$

An absence of meaningful choice includes oppression from this unequal bargaining position and surprise from the assertion of unexpected provisions. ${ }^{83}$ Courts will consider fine print clauses as well as high pressure tactics. ${ }^{84}$ The manner in which the contract was entered

${ }^{75}$ U.C.C. $\$ 2-302$ (1962).

${ }^{76}$ See 8 WILlistON ON CONTRACTS $§ 18$ (4th ed. 1999).

${ }^{77} \mathrm{Id}$.

${ }^{78} \mathrm{Id}$.

${ }^{79}$ See Cooper v. MRM Investment Co., 367 F.3d 493 (6th Cir. 2004).

${ }^{80}$ See Williams v. Walker-Thomas Furniture Co., 350 F.2d 445, 449-50 (D.C. 1965).

${ }^{81}$ Delinger, Inc. v. Dendler, 608 A.2d 1061, 1066-68 (Pa. Super. Ct. 1992).

${ }^{82}$ See Cooper, 367 F.3d at 502-04.

${ }^{83}$ See Graham v. Scissor-Tail, Inc., 28 Cal. 3d 807, 817-18 (Cal. 1981).

${ }^{84}$ See Brewer v. Missouri Title Loans, Inc., 323 S.W.3d 18, 22 (Mo. 2010), vacated, 131 S. Ct. 2875 (2011). 
into is important in determining whether there is an absence of meaningful choice. ${ }^{85}$ Courts will thus consider whether or not the weaker party had a reasonable opportunity to understand the terms. $^{86}$ Contracts of adhesion are often found to be procedurally unconscionable because these contracts are typically offered on a take-it or leave-it basis; the weaker party has no opportunity to negotiate the terms of the contract and is only left with the option of accepting the contract as is. ${ }^{87}$ A contract is not necessarily unconscionable solely based on a superior bargaining power. ${ }^{88}$ In case of Witmer v. Exxon Corp., although there was an inequality in bargaining power, negotiations were invited between Exxon and the plaintiffs, and thus, the court did not find that there was a lack of meaningful choice. ${ }^{89}$

In the reality television industry, there is a disparity in bargaining power between the contestants and the producers. $^{90}$ The producers have a high level of business acumen and experience. $^{91}$ In contrast, the contestants are typically ordinary people. On average, they do not have a high level of knowledge regarding the necessary precautions that should be considered when entering into an agreement with a producer. ${ }^{92}$ This is in contrast to famous actors in movies and on other television shows. ${ }^{93}$ Established actors are often aware of the necessary precautions and in fact, many have agents who are able to assess the legal consequences of the contracts they enter. ${ }^{94}$ Only the producers and the networks are involved in drafting the contracts. ${ }^{95}$ Additionally, it is unlikely that the contestants have the ability to change the terms in

\footnotetext{
${ }^{85}$ See Williams, 350 F.2d at 449.

${ }^{86}$ See Miller v. Corinthian Colleges, Inc., 769 F. Supp. 2d 1336, 1344 (D. Utah 2011).

${ }^{87}$ See Nagrampa v. MailCoups, Inc., 469 F.3d 1257, 1282 (9th Cir. 2006).

${ }^{88}$ Witmer v. Exxon Corp., 434 A.2d 1222, 1228 (Pa. 1981).

${ }^{89} \mathrm{Id}$.

${ }^{90}$ See HILL, supra note 6.

${ }^{91} \mathrm{Id}$.

${ }^{92}$ See Murray \& Ouellette, supra note 9, at 3-4.

${ }^{93}$ See Barnett, supra note 67, at 10-12.

$94 \mathrm{Id}$. at 17-18.

${ }^{95}$ See generally Sernes, supra note 5.
} 
the agreement. Contestant Jill Mouser was required to sign a second waiver before competing in the "harness of pain." 96 After winning a number of rounds of the competition and not being given a considerable time to consider the agreement, Houser likely signed without any explanation of the terms, and without a substantial opportunity to even consider the terms. ${ }^{97}$ Contestants are often rushed through the process of signing contracts. ${ }^{98}$ Due to such an inequality in bargaining power, reality program contracts are often procedurally unconscionable because of the lack of meaningful choice on behalf of the reality show contestants.

In addition to unequal bargaining power, substantive unconscionability, or terms unreasonably favoring one side, must exist in order for a contract to be unconscionable. ${ }^{99}$ Some courts have resorted to a sliding scale in determining unconscionability, whereby highly unreasonable terms favoring one side require less inequality in bargaining power and vice versa. ${ }^{100}$ In making a determination regarding whether terms of a contract unreasonably favor one side, courts look for,

[S] uch terms that impair the integrity of the bargaining process or otherwise contravene the public interest or public policy; terms (usually of an adhesion or boilerplate nature) that attempt to alter in an impermissible manner fundamental duties otherwise imposed by the law, fine-print terms, or provisions that seek to negate the reasonable expectations of the nondrafting party, or unreasonably and unexpectedly harsh terms having to do with price or other central aspects of the transaction. ${ }^{101}$

In Carll v. The Terminix International Company, the arbitration clause was held to be unconscionable based on the grounds that the terms unreasonably favored one side. ${ }^{102}$ The arbitration clause provided that damages would not be awarded for any personal injuries. ${ }^{103}$

\footnotetext{
${ }^{96}$ See Lawsuit: CBS Used "Harness of Pain”, supra note 1.

${ }^{97} I d$.

${ }^{98}$ See BRENTON \& COHEN, supra note 64, at 138.

99 See Armendariz, 6 P.3d 669, 696 (Cal. 2000).

${ }^{100}$ See CAL. CIV. CODE $\S 1670.5$ (West 1979).

${ }^{101}$ See 8 Williston ON CONTRACTS $\S 18: 10$ (4th ed. 1999).

${ }^{102}$ Carll v. Terminix Int'l Co., 793 A.2d 921, 925 (Pa. Super. Ct. 2002).
} 
Contracts in the reality television industry are long and complicated. ${ }^{104}$ Producers continue to add additional terms which benefit them as the risks in reality television increase. ${ }^{105}$ In determining whether reality program contract terms unreasonably favor one side, the language of certain provisions in The Real World contract will be construed. ${ }^{106}$ Provisions in the Real World contract include an attempt to disclaim responsibility for the following:

- You may die, lose limbs, and suffer nervous breakdowns.

- If you undergo any medical procedures while involved in the show, they carry the risk of infection, disfigurement, death.

- You may be humiliated and explicitly portrayed "in a false light."

- Producers are under no obligation to conduct background checks on your fellow cast members.

- If you contract AIDS or other sexually transmitted diseases while filming ["gonorrhea, herpes, syphilis, pelvic inflammatory disease (PID), Chlamydia, scabies (crabs),'hepatitis, genital warts, and other communicable and sexually transmitted diseases or Pregnancy; etc."], MTV is not responsible.

- Interacting with other cast members carries the risk of "non-consensual physical contact" and should you contract AIDS, etc. during such an interaction, MTV is not responsible.

- You grant the Producer blanket rights to your life story.

\footnotetext{
${ }^{103} I d$.

${ }^{104}$ Breeanna Hare, The 'Real World' of Reality Show Contracts, CNN (Dec. 30, 2009), http://articles.cnn.com/200912-30/entertainment/legal.reality.contracts_1_show-hopefuls-reality-show-contracts?_s=PM:SHOWBIZ. ${ }^{105} \mathrm{Id}$

${ }^{106}$ See Camille Dodero, We Have Obtained a Copy of MTV's Standard Real World Cast-Member Contract, VoICE (Aug. 1, 2011), http://blogs.villagevoice.com/runninscared/2011/08/mtv_real_world_contract.php?page=2.
} 
- The Producer can do pretty much anything they want with your life story, including misrepresentation.

- Your email may be monitored during participation.

- The production crew can show up at your personal house at any time to film and/or to take anything they want, as long as they return the objects once production has ended.

- Under ordinary circumstances, all of this would be considered a "serious" invasion of privacy.

- For one year after the show's final episode airs, cast members are required to participate in all producer-determined press and forbidden from engaging in any media (radio, television, chat rooms, blogs) without the Producer's written permission.

- The Producer holds the authorship and copyright to every photograph, email, website, sound or video recording, documented performance created in relation to the program, on every medium imaginable.

- You're obligated to participate in a Reunion Special for up to five years after the show ends, you'll be paid $\$ 2500$ for your involvement, and the Producer only has to give you 14 days notice.

- You're required to participate in book or home video projects for two years after the show ends, and you'll be paid $\$ 750.00$ for each one. ${ }^{107}$

The Real World contract language essentially attempts to shift any liability from the producer to the contestant. If this contract is deemed enforceable, contestants essentially waive all rights to recover any damages pertaining to illness, death, injury, emotional distress,

${ }^{107}$ Id. 
defamation, rape, First Amendment rights to freedom of speech, and privacy rights, as they relate to the producer. This is not to say that a contestant could not bring a legal action against another contestant or third party. Yet, by this long list of waivers, it seems that the terms of this contract unreasonably favor the producer. A term attempting to protect the producer from any liability due to any physical damages seems to be against public policy, against the reasonable expectations of the nondrafting party, and unexpectedly harsh.

Another common provision in many reality show contracts, not included in The Real World terms aforementioned, is a confidentiality provision. This type of provision requires contestants to pay a large fine if they "spill the beans" on a mystery or outcome in a reality program before it airs on television. For example, contestants on The Bachelor and The Bachelorette are reportedly required to sign a confidentially agreement which inflicts a penalty of $\$ 5$ million to any contestant who leaks information about the show. ${ }^{108}$ Similar to the provisions in The Real World contract, this penalty seems to be unreasonably harsh against the nondrafting party (i.e., the contestant) because of the exorbitantly high fine.

Despite the seemingly unequal bargaining power and the extreme nature of the terms of The Real World contract, unconscionability has become increasingly difficult to prove. ${ }^{109}$ In terms of bargaining power, parties are free to contract as they please. ${ }^{110}$ Although some of the contestants may be in desperate situations where they feel that they have no alternatives, they are still free to walk away from the contract. In fact, most contestants do not sign on because they

\footnotetext{
${ }^{108}$ See Daynah Burnett, The Bachelorette's Jef Holm Reveals Details of His Multi-Million Dollar Confidentiality Contract, WETPAINT (Sept. 4, 2012), http://www.wetpaint.com/the-bachelorette/articles/the-bachelorettes-jef-holmreveals-details-of-his-multi-million-dollar-confidentiality-contract.

${ }^{109}$ See 8 WILLISTON ON CONTRACTS $\S 18$ (4th ed. 1999).

${ }^{110} \mathrm{Id}$.
} 
are desperate; rather, they sign on because they are often looking for their chance at fame. ${ }^{111}$ Additionally, it is unlikely that the producers inflict severe pressure on contestants to sign because of the fact that the contestants are fairly dispensable. ${ }^{112}$ In determining whether contract terms unreasonably favor one side, courts will consider whether the terms are in fine-print. ${ }^{113}$ In the aforementioned Real World contract, these terms were in fact, not in fine-print nor were they hidden in the contract. ${ }^{114}$ It appears that some contestants are aware of the consequences of the terms that they are agreeing to in the contracts. Jef Holm mentioned how he consistently deflected any questions regarding what happened on The Bachelorette because he did not want to be liable for breaching his confidentiality agreement. ${ }^{115}$

Although unconscionability is difficult to prove, combining unequal bargaining power between many producers and contestants on reality programs with the unreasonably harsh terms, this high burden of proof is likely to be met in certain contracts. Yet, contestants should be aware that courts do not easily declare contracts unconscionable. For any individuals wanting to be the next Bachelor, Survivor, Real World contestant, or contestant on any reality program, they should take the time to read the contract, be aware of the rights they are waiving in order to be in the spotlight, and request modifications to the contract if they are unwilling to accept the contract as written. There is no guarantee that these contracts will be ruled unenforceable despite the producers' superior bargaining position and the harsh terms within many reality program contracts.

\footnotetext{
${ }^{111}$ See Andrea L. Press \& Bruce A. Williams, Fame and Everyday Life: The "Lottery Celebrities" of Reality TV, in The BlackWEll Companion to the Sociology OF Culture 176 (Mark D. Jacobs \& Nancy Weiss Hanrahan eds., 2005).

112 Sue Collins, Making the Most out of 15 Minutes: Reality TV's Dispensable Celebrity, 9 TELEVISION \& NEW MEDIA 87 (2008).

${ }^{113}$ Luna v. Household Fin. Corp. III, 236 F. Supp. 2d 1166, 1175 (W.D. Wash. 2002).

${ }^{114}$ See Dodero, supra note 106.

115 See Burnett, supra note 108.
} 


\section{EMPLOYEE VERSUS INDEPENDENT CONTRACTOR}

In addition to waivers of rights within the contract terms, another method for the reality television producers to avoid liability is by demonstrating that they hire actors or contestants as independent contractors rather than as employees. This distinction is of importance because, generally, an employer can be held vicariously liable for torts of an employer, but not those of an independent contractor. ${ }^{116}$ Other benefits stemming from an employer-employee relationship include: benefits under the Unemployment Insurance Act and the Workers' Compensation Act, among others. ${ }^{117}$

In determining whether an individual is an employee or an independent contractor, courts typically employ a totality of circumstances approach. ${ }^{118}$ Most courts consider the following factors in determining whether an individual is an employee or an independent contractor: (1) the extent of control the employer exercises over the work; (2) the skill required to complete the job; (3) whether the employed is engaged in a distinct business or occupation; (4) whether the work is being performed under the direction of the employer or without supervision and whether this is common; (5) who supplies the tools, instruments and place of work; (6) the length of employment; (7) the method of payment; (8) whether the work constitutes the regular business of

\footnotetext{
${ }^{116}$ Bostrom v. San Bernardino, 42 Cal. Rptr. 2d 669 (Ct. App. 4th Dist. 1995); Millsap v. Fed. Express Corp., 227 Cal. App. 3d 425 (Ct. App. 1st Dist. 1991); Green v. Soule, 78 P. 337 (Cal. 1904). See also CAL. JuR. 3D Employer and Employee $\S \S 129-134$.

${ }^{117}$ See Empire Star Mines Co. v. California Emp't Comm'n, 168 P.2d 686 (Cal. 1946) (overruled on other grounds by, People v. Sims, 651 P.2d 321 (Cal. 1982)). See also S. G. Borello \& Sons, Inc. v. Dep't of Indus. Relations, 769 P.2d 399 (Cal. 1989); Gonzalez v. Workers' Comp. Appeals Bd., 54 Cal. Rptr. 2d 308 (Ct. App. 2d Dist. 1996); Furtado v. Schriefer, 280 Cal. Rptr. 16 (Ct. App. 1st Dist. 1991); 60 CAL. JUR. 3D Unemployment Compensation; 65 CAL. JUR. 3D Work Injury Compensation §§ 143-146.

${ }^{118}$ Oshiver v. Levin, Fishbein, Sedran \& Berman, 910 F. Supp. 225 (E.D. Pa. 1996), order aff'd, 96 F.3d 1434 (3d Cir. 1996).
} 
the employer; and (9) whether the individual and the employer believed that they entered into an employer-employee relationship. ${ }^{119}$

The extent to which an employer has control over the work of the employed is the most significant factor in determining whether the employed is an employee or an independent contractor. ${ }^{120}$ The more control an employer has over the details of the work, the more likely it is that an employer-employee relationship exists. ${ }^{121}$ Additionally, "it is the right and not the exercise of control which is the determining element." ${ }^{\prime 22}$ In reality television, producers have a large degree of control over participants. Producers determine the activities that the contestants will perform. ${ }^{123}$ Producers also control where the contestants will perform those activities: whether taking them to a house in New Jersey or sending them to a Brazilian jungle. ${ }^{124}$ In reality television, the cameras are almost always recording the contestants' activities and the participants are, in effect, constantly serving the producers.

Next, the skill required to complete the job is another factor in this multi-factor test for determining whether an independent contractor or an employee relationship exists. The more skill required, the more likely the employed individual is to be an independent contractor. ${ }^{125}$ In the case of reality television, a high skill level is rarely required. In fact, one of the popular features of many reality shows is that they often star ordinary people. ${ }^{126}$ This aspect of reality

\footnotetext{
${ }^{119}$ See 19 WILLISTON ON CONTRACTS $§ 54$ (4th ed. 1999).

${ }^{120}$ See Morante v. Am. Gen. Fin. Ctr., 157 F.3d 1006 (5th Cir. 1998); Campbell v. Keystone Aerial Surveys, Inc., 138 F.3d 996 (5th Cir. 1998); Conasauga River Lumber Co. v. Wade, 221 F.2d 312 (6th Cir. 1955); G.E. Tignall \& Co., Inc. v. Reliance Nat. Ins. Co. (D. Md. 2000).

${ }^{121}$ See 19 WILLISTON ON CONTRACTS § 54 (4th ed. 1999).

${ }^{122} I d$.

${ }^{123}$ SURVIVOR LESSONS: ESSAYS ON COMMUNICATION \& REALITY TELEVISION 82 (Matthew J. Smith \& Andrew F. Wood eds., 2003).

${ }^{124}$ See Jersey Shore, MTV, http://www.mtv.com/shows/jersey_shore/season_1/series.jhtml (last visited Nov. 2, 2012); Survivor: Tocatins, SIDEREEL, http://www.sidereel.com/Survivor_Tocantins (last visited Nov. 2, 2012).

${ }^{125}$ See Ascoli v. Hinck, 256 S.W.3d 592, 594 (Mo. Ct. App. 2008).

${ }^{126}$ HILL, supra note 6.
} 
television allows viewers to relate, in a sense, to the contestants. ${ }^{127}$ For instance, Jersey Shore follows eight housemates who spend their summer at the Jersey Shore. ${ }^{128}$ Although the show has made them into celebrities, they show no particular skillset on the show. Episodes often revolve around partying, drinking, sex, working out, fighting, and relationships. ${ }^{129}$ Some reality programs such as Man v. Food require a higher level of skill. ${ }^{130}$ In this program, Adam Richman travels around the country exploring the cuisine different cities have to offer. ${ }^{131}$ Adam needs the ability to critique food as well as the ability to consume a large amount of food because the series often features him participating in eating challenges at the local restaurants he visits. ${ }^{132}$

Courts will consider whether the employed individual is engaged in a distinct business or occupation. If this inquiry is answered in the affirmative, the employed is more likely to be found to be an independent contractor. ${ }^{133}$ The cast of reality television is often not engaged in the business of acting. Reality programs are typically unique in that the cast is made up of nonactors with whom the audience can relate. ${ }^{134}$ Although this is not true for all reality programs, it is commonly the case. Because of the popularity of particular reality programs, cast members have frequently garnered fortune, fame, and a career out of reality television. Thus, reality program cast members who were not actors originally, may have developed a more distinct business throughout the show. However, when they are originally hired, the majority of reality show casts are in fact just ordinary people. ${ }^{135}$

\footnotetext{
${ }^{127} I d$.

${ }^{128}$ The show has been filmed in locations other than the Jersey Shore as well. See Jersey Shore, supra note 124.

${ }^{129}$ See id.

${ }^{130}$ See Man v. Food, TRAVEL CHANNEL, http://www.travelchannel.com/tv-shows/man-v-food/articles/man-v-foodnation (last visited Nov. 2, 2012).

${ }^{131} \mathrm{Id}$.

${ }^{132} \mathrm{Id}$.

${ }^{133}$ Ascoli, 256 S.W.3d at 594.

${ }^{134}$ HILL, supra note 6, at 98.

${ }^{135} \mathrm{Id}$.
} 
Additionally, courts will look to whether the work is being performed under the direction of the employer or without supervision, and whether this is common. Work performed under the direction or supervision of the employer points towards an employee relationship. ${ }^{136}$ The day-today activities of the reality show cast are supervised. ${ }^{137}$ Similar to the element of control, the contestants and the participants are subject to the direction of the producers. They are constantly being watched, and producers have the ability to make essentially all the decisions despite the unscripted nature of reality programs.

If the employer furnishes the tools, instruments and place of work, the relationship is more likely to be characterized as that of an employer-employee. ${ }^{138}$ Recent reality shows often provide the environment or place of work. Participants are often shipped off to a house or an alternate location for the filming. In these instances, the network and the producers provide the participants with all the resources that they need. For example, when a participant joins The Bachelor Pad, they are shipped to the location. ${ }^{139}$ Although they bring their own clothes and belongings, they are essentially provided everything with which they interact - food and beverages, pools, contests etc. In reality show programs where the cast is filmed in their own homes, for example, this factor would tend to point more towards an independent contractor relationship because in those situations, the cast is providing their own "tools, instruments and place of work." Thus, this factor can skew the distinction between an independent contractor and an employee, depending on the nature of the reality show, where it is filmed, and who provides the activities, resources etc.

\footnotetext{
136108 AM. JUR. 3D Proof of Facts 247 (2009).

${ }^{137}$ SURVIVOR LESSONS, supra note 123, at 77, 81-82.

${ }^{138}$ Harris v. Vector Mktg. Corp., 656 F. Supp. 2d 1128, 1135 (N.D. Cal. 2009).

139 See Bachelor Pad: About the Show, ABC, http://beta.abc.go.com/shows/bachelor-pad/about-the-show (last visited Nov. 2, 2012).
} 
Courts will also consider the length of employment when determining whether a particular individual is an independent contractor. The longer the employment period, the more likely the individual is to be considered an employee. ${ }^{140}$ If the individual is employed for a short, specified period of time, the individual is more likely to be found to be an independent contractor. ${ }^{141}$ This factor tends to favor an independent contractor relationship in the case of a reality television cast because they are often employed for a particular time period or project, namely, a season of the show. Yet, reality television programs that span multiple seasons with the same cast and with longer contractual periods may very well point towards an employeremployee relationship.

Another factor considering the determination is the method of payment. ${ }^{142}$ If the participants are paid hourly, weekly or monthly, this is characteristic of employment relationships. ${ }^{143}$ In contrast, if contestants are paid in a lump sum for completion of a project or on commission, this is more characteristic of an independent contractor relationship. ${ }^{144}$ In reality television contracts, many contestants are not paid at all or are paid a minimal lump sum. ${ }^{145}$ Although some reality shows are in opposition to this practice, this factor tends to support an independent contractor relationship.

Courts will often also consider whether the work constitutes the regular business of the employer. If the work being performed by the individual does constitute the regular business of the employer, it is more likely that the employed individual is acting as an employee. ${ }^{146}$ Independent contractors are more frequently hired in cases where the business is different than

\footnotetext{
${ }^{140}$ See 19 WILLISTON ON CONTRACTS $§ 54$ (4th ed. 1999).

${ }^{141} I d$.

${ }^{142} I d$.

143108 AM. JUR. 3D Proof of Facts 247 (2009).

${ }^{144} I d$.

${ }^{145}$ See Edward Wyatt, On Reality TV: Tired, Tipsy, and Pushed to Brink, N.Y. TiMES, Aug. 2, 2009, at A1.

${ }^{146}$ See id.
} 
that of the employer's business. ${ }^{147}$ In the instant analysis, the producers of reality television are involved in the reality television business. Although they themselves are not involved in the acting component of the business, the companies employing the cast often exist for this primary purpose - producing different reality television shows. Thus, in the case of reality television, this factor also tends to point more towards an employer-employee relationship.

Lastly, courts will consider whether the individual and the employer believed they entered into an employer-employee relationship. If this was the case, courts are more likely to give effect to both parties' intent. Yet, a written contract describing a relationship as one of an employee or an independent contractor is not conclusive. ${ }^{148}$ Rather, the realities of the relationship control the determination. ${ }^{149}$ Although producers attempt to classify the relationship as one of an independent contractor, it is often unclear whether participants think they are an employee or an independent contractor, especially because it is likely that many participants do not thoroughly read the contracts.

In summary, factors tending to point to an employer-employee relationship in the reality television context include the extent of control the producer exercises over the work, the fact that most contestants are not engaged in a distinct business or occupation, the work of the contestants is performed under the direction of the producer, and the fact that the work constitutes the regular business of the employer. Factors tending to support an independent contractor relationship include the method of payment and the length of employment. Depending on the nature of the reality show, the skill required to complete the job, the supply of tools, instruments and place of work, and whether the individual and the employer believed to have entered into an employer-employee relationship, could point towards either an employee-employer relationship

\footnotetext{
${ }^{147} \mathrm{Id}$.

${ }^{148}$ Morante v. Am. Gen. Fin. Ctr., 157 F.3d 1006 (5th Cir. 1998).

${ }^{149}$ MacDougall v. Weichert, 677 A.2d 162 (NJ 1996).
} 
or one of an independent contractor. A majority of factors, including the most important factoremployer's control over the work of the employee - tend to suggest an employer-employee relationship. By imposing this type of relationship, courts would provide more benefits to the cast members, while also imposing the possibility of liability on the producers for the participants' activities against third parties.

\section{RESOLUTION AND CONCLUSION}

With the proliferation and popularity of reality television programs, more dangerous and obscure reality television shows have arisen. Resultantly, more risks are present to both the cast and third parties including psychological, physical, and financial damages.

Special considerations should be accorded to reality television outside of the typical film considerations. Reality television producers want to see real life action on their shows. They do not want the mundane on their programs; rather, they promote and encourage dangerous situations in which contestants put their bodies in harm's way. Producers promote reality programs as train wrecks, encouraging drinking which tends to lead to increased fighting and danger. Viewers are drawn to these shows as evidenced by the popularity of reality shows in the past decade.

Producers are well-aware of the dangers presented by their shows. Thus, they attempt to draft contracts to avoid liability to the contestants, by having them waive essentially any rights that could be implicated. Additionally, producers seek to hire contestants as independent contractors in order to avoid liability to third parties as well as any benefits arising out of an employer-employee relationship. 
Producers of reality television programs are in a superior bargaining position compared to the reality show contestants who are typically ordinary people. Additionally, many terms in reality contracts seem to be unreasonably unfair to the contestants. These factors suggest that some reality television contracts, or at least some terms therein, would be unconscionable and thus unenforceable. Additionally, in a number of reality shows, it is likely that the relationship between the participants and the producers is better aligned with that of an employer-employee relationship as opposed to an independent contractor relationship.

Because of the unique nature of reality television, whereby the actors are ordinary people and are encouraged to act in certain ways that draw fans but also have risks, courts should critically examine the actions of the producers. While still allowing for parties to contract as they please, the imposition of responsibility on producers is important where the situation dictates an unconscionable term or contract or where the classification of an employer-employee relationship is warranted.

Both producers and contestants should take steps to ease these concerns. Producers should avoid rushing participants through the contracts, giving them a reasonable opportunity to read and understand the terms and allowing for negotiations. By doing so, producers can continue to celebrate reality television by providing veracity to the contracting process. Such contracts will likely be more enforceable because there will be less of a chance of unequal bargaining power and unfair terms. Contestants should also take precautions before signing on to the next reality television program. It is crucial for contestants to realize that despite the shocking terms in the contracts, courts are not quick to find contracts unconscionable. Contestants must be aware that the terms may be enforceable and thus, before entering into a contract, they should read the contract, discuss the contract with an agent or attorney if they 
cannot reasonably understand the terms of the contract or have other concerns. Contestants should also attempt to negotiate or walk away from the contract if they are not willing to accept the risks inherent in reality television contracts. 